Lentera Pustaka: Jurnal Kajian Ilmu Perpustakaan, Informasi dan Kearsipan, 4 (2): 67-78, 2018

Copyright (O2018, ISSN: 2302-4666 print/ 2540-9638 online

Available Online at: http://ejournal.undip.ac.id/index.php/lpustaka

\title{
Pemanfaatan E-Journal oleh Mahasiswa pada Perpustakaan Perguruan Tinggi di Jakarta
}

\author{
Hendra Wicaksono ${ }^{1 *}$ \\ ${ }^{1}$ Jurusan Ilmu Perpustakaan, Fakultas Teknologi Informasi, Universitas YARSI, \\ Jl. Letjend Suprapto Sempaka Putih Jakarta, Indonesia. \\ ${ }^{*}$ Korespondensi: hendra.wicaksono@yarsi.ac.id
}

\begin{abstract}
[Title: E-journal usage by University Students at the University Libraries in Jakarta] This research analyzed the utilization of e-journal by college students in Jakarta. This study applied quantitative research by using descriptive method. To gain the data, questionnaire, observation, and interview were used by the researcher. This study was conducted by delivering a questionnaire consisting of 19 questions accompanied by interview to 122 students and librarians. The data that has been processed was analyzed by using likert scale based on Strength, Weakness, Opportunities and Threats (SWOT). The study revealed that 114 respondents (93.44\%) responded positively to the Ejournal facility and A total of $22(18.03 \%)$ of respondents answered often difficulties in utilizing E-Journal. This difficulty occurs because they do not know that the E-Journal provided by the library can be accessed from home. there were $30(24.59 \%)$ respondents answered very positive, as many as $90(73.77 \%)$ respondents answered positive, $2(1.63 \%)$ respondents answered negative. It can be concluded that the students very enthusiastic about the e-Journal facility that subscribed. From the question about the service of E-Journal in the library, $6(4.91 \%)$ respondents answered very well, $92(75.40 \%)$ respondents answered well, and $24(19.67 \%)$ respondents said not good. Then it can be seen that the students rate the E-Journal service that subscribed quite well.
\end{abstract}

Keywords: Utilization of E-journal; E-journal; University Library; Student Perspective; Quantitative research

\begin{abstract}
Abstrak
Penelitian ini menganalisis pemanfaatan ejournal oleh mahasiswa pada perguruan tinggi di Jakarta. Penelitian ini menggunakan pendekatan kuantitatif dengan menggunakan metode diskriptif. Pengumpulan data dilakukan dengan penyebaran kuesioner, observasi, dan wawancara. Penelitian dilakukan dengan cara penyebaran kuesioner pada 122 responden berisi 19 butir pertanyaan pada mahasiswa dan pustakawan disertai dengan wawancara. Proses terakhir peneliti melakukan analisis data yang sudah di olah menggunakan software Microsoft Excel 2013. Data yang telah diolah, dianalisis menggunakan skala likert berdasarkan teori SWOT strength (Kekuatan), Weakness (Kelemahan), Oppurtinities (Peluang), dan Threats (ancaman). Hasil penelitian menunjukkan bahwa mayoritas responden menjawab positif tentang fasilitas E-Journal yang dilanggan namun sebagian kecil responden menjawab sering kesulitan dalam memanfaatkan E-Journal . Kesulitan ini terjadi karena tidak mengetahui bahwa E-Journal yang disediakan oleh perpustakaan dapat diakses dari rumah. Maka dapat dilihat bahwa mahasiswa sangat antusias terhadap fasilitas E-Journal yang dilanggan. Kemudian dari pertanyaan tentang layanan ejournal di perpustakaan, dapat dilihat bahwa mahasiswa menilai layanan E-Journal yang dilanggan cukup baik.
\end{abstract}

Kata kunci: Pemanfaatan journal elektronik; E-journal; Perpustakaan Perguruan Tinggi; Perspektif Mahasiswa; Penelitian Kuantitatif

\section{Pendahuluan}

E-journal adalah suatu bentuk digitalisasi ilmu pengetahuan yang memungkinkan pengguna mengakses secara mudah serta dengan manajemen kerja sama (berlangganan) antar perpustakaan lain, institusi atau E-Journal lainnya, maka kebutuhan akan ilmu pengetahuan yang bervariatif dan terbaru (up date) akan terpenuhinya ( Mustati \& M. Najib HM 2013, p. 102). Menurut PDII LIPI Jurnal elektronik adalah sarana berbasis web untuk mengelola sebuah jurnal ilmiah maupun non ilmiah. Sarana ini disediakan sebagai wadah bagi pengelola, penulis, dan pembaca karya-karya ilmiah. E-journal seharusnya banyak dibutuhkan oleh para peniliti ilmuwan, dosen dan mahasiswa karena e-journal memuat artikel hasil-hasil penelitian yang dapat diakses secara online. 
Hasil penelitian di PEC University of Technology, Chandigardh, India bahwa para pengguna generasi muda telah nyaman mengadopsi budaya baca elektronik, tetapi penggunaan E-Journal membutuhkan semacam keahlian teknis. Kurangnya pelatihan di kalangan pengguna adalah faktor memotivasi utama dalam penggunaan E-Journal, rata-rata para penggunanya ialah para Pasca Sarjana dan rata-rata umur nya ialah 23-30 tahun yang sering menggunakan fasilitas E-Journal (vasishta, S. \& Navijyoti, 2011).

Perpustakaan Perguruan Tinggi dalam kaitannya sebagai pusat penelitian dituntut untuk bisa menyediakan sumber-sumber informasi relevan yang mampu menunjang dalam penilitian. Jurnal diketahui sebagai salah satu literatur terbitan berseri yang relevan yang dapat menunjang kegiatan tersebut (Ibnu Rusydi, 2013 hlm.200). Perguruan tinggi adalah suatu lembaga pendidikan yang dikhusus kan untuk tingkat lanjut dari pendidikan formal. Perguruan tinggi juga harus memiliki perpustakaan untuk menunjang pendidikan didalamnya. Banyak sekali perguruan tinggi yang menyediakan fasilitas E-Journal dengan anggaran yang tidak sedikit untuk menunjung pembelajaran di kampus.

Salah satunya adalah Universitas Yarsi sebagai salah satu Perguruan Tinggi Terbesar di Jakarta Pusat. Universitas Yarsi melanggan E-Journal seperti : Ebsco, Gale, dan Proquest. Dana yang disediakan sebesar Rp.100.000.000,00 (seratus juta rupiah) dalam 1 paket (Siti Nurningsih,2017,15 Februari). Perguruan tinggi lain yang telah melanggan E Journal adalah Universitas Trisakti sesuai pada pengamatan penulis di website perpustakaan terdapat 14 Jurnal Internasional seperti: Proquest, Ebrary, Emerald, Ebsco, Cenange, geoscienceworld, Universa Medicine dan beberapa jurnal besar lainnya. Dengan kebijakan yang sangat bagus dan anggaran yang begitu besar, muncul sebuah pertanyaan apakah kebijakan tersebut sudah dimanfaatkan secara maksimal oleh mahasiswa. Pertanyaan ini yang belum banyak dikaji oleh penelitianpenelitian sebelumnya tentang pemanfaatan e-journal oleh mahasiswa diperguruang tinggi di Jakarta. Oleh karena itu dipenelitian ini, penulis mengeksplorasi lebih lanjut mengenai sejauh mana pemanfaatan EJurnal oleh Mahasiswa Perguruan Tinggi di wilayah Jakarta.

\subsection{Koleksi Perpustakaan}

Koleksi merupakan aset dari suatu perpustakaan. Semakin bertambahnya zaman dan kebutuhan maka perpustakaan juga harus mengikutinya. Dahulu koleksi perpustakaan bertumpu pada koleksi cetak dan media audiovisual yang masih berformat analog, maka di era sekarang, pengembangan koleksi untuk perpustakaan mengarah ke koleksi digital (Pawit M.Yusup , 2012 hal 237).Pengembangan Koleksi perpustakaan mencakup:

a. Jumlah, Mencakup judul, jenis dan eksemplar

b. Terbitan baru (Mutakhir)

c. Variasi, baik yang tercetak seperti buku, majalah, koran maupun yang terekam seperti film, VCD, kaset, elektronik.

d. Sumber penerbitannya, makin banyak

e. Sumber asalnya, dalam negeri (Bahasa Indonesia dan Bahasa daerah). Dari luar negeri, terjemahan, bahasa inggris, dan bahsa lainnya.(Sutarno, 2004 hal 91)

Pada saat ini banyak koleksi yang disediakan oleh perpustakaan seperti E-Book, Ejournal, dan sebagainya. Hal ini bertujuan agar para para pengguna dapat mengakses informasi dari manapun atau kapanpun. Sehingga para pengguna dapat merasa puas atas pelayanan yang disediakan oleh perpustakan. Jika pengguna merasa puas, akan berdampak terhadap mutu, kualitas dan kuantitas perpustakaan tersebut.

\subsection{Ejournal}

LIPI (Dalam : http://www.jurnal. lipi.go.id/utama.cgi/bantuan) Jurnal elektronik adalah sarana berbasis web untuk mengelola sebuah jurnal ilmiah maupun non ilmiah. Sarana ini disediakan sebagai wadah bagi pengelola, penulis, dan pembaca karya-karya ilmiah. Menurut Mien A.Rifai di 2008 (dikutip Thamrin Hasan hlm.26) Jurnal elektronik adalah terbitan berkala yang berbentuk pamphlet berseri berisi bahan yang sangat diminati orang saat diterbitkan secara on-line setelah dilakukan proses digitalisasi. EJournal yang dapat diakses secara online seharusnya lebih banyak diminati karena aksesnya yang dapat digunakan selama 24 jam, Akses ke journal online didapatkan ketika perpustakaan telah melakukan langganan, Atau perpustakaan itu sendiri mempunyai stok beberapa jurnal (Ibnu Rusydi hlm.202). Kesimpulan yang dapat ialah E-Journal merupakan alat/sarana berbasis website yang di khsusukan untuk mengelola jurnal bebrbasis elektronik dan diterbitkan secara online, dapat digunakan selama 24 jam untuk memenuhi kebutuhan pengguna/user dari perpustakaan tersebut. 
Tabel 1. Perbedaan E-Journal dan jurnal (Sawitry,2010 )

\begin{tabular}{|c|l|l|l|}
\hline No. & \multicolumn{1}{|c|}{ Kriteria } & \multicolumn{1}{c|}{ Elektronik } & \multicolumn{1}{c|}{ Tercetak } \\
\hline 1 & Kemutakhiran & Mutakhir & Mutakhir \\
\hline 2 & Kecepatan diterima & Cepat & Lambat \\
\hline 3 & Penyimpanan & Fleksibel & Memakan Tempat jam \\
\hline 4 & Pemanfaatan & Terbatas pada jam & buka \\
\hline 5 & Kesempatan & Akses bisa bersamaan & Antri \\
\hline 6 & Penulusuran & Otomatis Tersedia & Harus dibuat \\
\hline 7 & Waktu Penulusuran & Cepat & Lama \\
\hline 8 & Keamanan & Lebih aman & Kurang Aman \\
\hline 9 & Manipulasi dokumen & Sangat mudah & $\begin{array}{l}\text { Tidak bisa } \\
\text { kutipan dsb) }\end{array}$ \\
\hline 10 & $\begin{array}{l}\text { Apabila berlangganan } \\
\text { dengan dana yang sama } \\
\text { (Jurnal Lokal) }\end{array}$ & Judul lebih bisa banyak & Judul Lebih sedikit \\
\hline 11 & Harga Total Berlangganan & Jauh Lebih Murah & Lebih Mahal \\
\hline
\end{tabular}

\subsection{Manfaat Ejournal}

Manfaat E-Journal memang tidak setiap para pengguna dapat merasakannya, hanya beberapa golongan saja seperti para peniliti, mahasiswa maupun dosen. Seperti diketahui bahwa E-Journal bukan bacaan umum seperti buku fiksi yang hamper semua orang pernah membacanya. Tetapi manfaat yang di peroleh cukup banyak. Beberapa manfaat adanya E-Journal diantaranya adalah:

a. Merangsang minat baca.

b. Memudahkan akses dan publikasi secara luas.

c. Meningkatkan daya saing, kualitas. kreatifitas, ilmu dan pengetahuan para peneliti/penulis.

d. Pembuktian kualitas dan kredibilitas institusi penerbit yang pada akhirnya menjadi media promosi.

e. Meningkatkan rangking perguruan tinggi. (Ibnu Rusydi hlm 205-206)

Dalam Pemanfaat E-Journal, ada beberapa situs E-Journal tidak berbayar seperti DOAJ (Directory of Open Access Journals). Situs ini menyediakan banyak nya penelitian,terlebih untuk bidang ekonomi. File yang tersedia dari Vol. 2, 1-4, 1998-Vol. 15, 1, 2011Diterbitkan oleh KementrianPendidikan, Penelitian dan Remaja, Romania. Ini berfokus padaInformatika ekonomi, masyarakat Informasi ,Sistem informasi, dan teknologi informasi (Kausal Chauan,2012). Menurut hasil penelitian pemanfaatan E-Journal Universitas Riau mahasiswa pada umumnya menggunakan E-Journal 1-2 kali seminggu, melakukan penulusuran 1-2 jam dan menjadi hambatan ialah bahasa asing (Thamrin Hasan, 2013).

\section{Metode Penelitian}

Jenis penelitian yang dilakukan dalam penelitian adalah kuantitatif. Data kuantitatif adalah data yang berbentuk angka atau data kualitatif yang diangkakan/scoring (Sugiyono,2015 hal.6). Metode penelitian kuantitatif dapat diartikan sebagai metode penelitian yang berlandaskan pada filsafat positivisme, digunakan untuk meneliti pada populasi atau sampel tertentu pengumpulan data menggunakan instrumen penelitian, analisis data bersifat kuantitatif/statistik dengan tujuan untuk menguji hipotesis yang telah ditetapkan (Sugiyono,2015 hal.11). Neuman W Laurence (2003) (dikutip dari Sugiyono,2015) Penelitian survey adalah penelitian kuantitatif,dalam penelitian survey peneliti menanyakan kebeberapa orang (yang disebut responden) tentang keyakinan, pendapat, karakterisitik suatu objek dan perilaku yang telah lalu atau sekarang. Metode penetilitian yang dipilih peniliti adalah Metode Deskriptif.

Dalam penelitian ini kriteria sampel adalah pengunjung yang ada di UPT Perpustakaan Universitas YARSI dengan jumlah sampe sebanyak 122 responden dengan jumlah kuesioner sebanyak 18 butir.

\subsection{Jenis dan Sumber Data}

Jenis dan sumber data dalam penelitian ini ada dua, yaitu data primer, merupakan data yang diperoleh langsung dari responden melalui kuesioner, dan data sekunder, merupakan data yang bersumber dari buku, jurnal, proseding, dan dokumen lain yang mendukung dan berhubungan dalam penelitian ini. 


\subsection{Teknik Analisis Data}

Tahapan dalam menganalisa data dilakukan dengan du acara, yang pertama adalah reduksi data Reduksi data merupakan proses pemilihan, pemusatan perhatian pada penyederhanaan, pengabstrakan, transformasi data kasar yang mucul dari catatan-catatan lapangan(Miles dan Huberman 1992:16 yang dikutip oleh N.Sari,2013). Merangkum dan memilih hal -hal yang sudah diperoleh dari hasil observasi dan kuesioner. Selanjutnya peniliti memfokuskan pada hal penting tentang pemanfaatan E-Journal oleh mahasiswa dan dosen.

Yang kedua, penyajian data dimana penyajian data berdasarkan hasil tabulasi.menurut sudiyono(yang dikutip Niken Dwi Sawitry hal. 10) dengan rumus $\mathrm{p}=\mathrm{f} / \mathrm{n}$ x $100 \%$. P menyatakan presentasi yang dicari, sementara $\mathrm{F}$ menyatakan frekeunsi jawaban, dan $\mathrm{N}$ adalah jumlah jawaban subyek. Secara khusus data dianalisis dengan menggunakan Skala Likert. Skala likert digunakan untuk mengukur sikap, pendapat, dan persepsi seseorang atau sekelompok orang tentang fenomena sosial(Sugiyono,2012 hal.134). Jawaban dalam skala likert ialah:
a. Sangat Setuju
a.Selalu
b. Setuju
b.Sering
c.Ragu-ragu
c.Kadang-kadang
d.Tidak Setuju
d.Tidak Pernah
e.Sangat Tidak Setuju
a. Sangat Positif
a.Sangat Baik
b. Positif
b. Baik
c. Negatif
c. Tidak Baik
d. Sangat Negatif
d. Sangat Tidak Baik

Untuk mempermudah analisis dibutuhkan skor dalam setiap jawaban dalam skala likert adalah sebagai berikut:

a.Setuju/selalu/sangat diberi skor $\quad 5$

b.Setuju/sering/positif diberi skor 4

c.Ragu-ragu/Kadang-kadang/Netral diberi skor 3

d.Tidak Setuju/hampir tidak pernah/negative diberi skor $\quad 2$

e.Sangat tidak setuju/tidak Pernah diberi skor 1

\section{Hasil dan Pembahasan}

\subsection{Kuesioner}

4.1.1 Pertanyaan 1

Pertanyaan 1 tentang keakuaratan E-Journal di adalah sebagai berikut :

Tabel 2. Keakuratan E-Journal

\begin{tabular}{|l|l|l|l|}
\hline Pertanyaan 1 & Pilihan Jawaban & Frekuensi & Presentase \\
\hline \multirow{4}{*}{$\begin{array}{l}\text { Seberapa sering keakuratan E- } \\
\text { Journal yang dilanggan }\end{array}$} & Sangat Baik & 6 & 4,91 \\
\cline { 2 - 4 } & Baik & 98 & 80,32 \\
\cline { 2 - 4 } & Tidak Baik & 18 & 14,75 \\
\cline { 2 - 4 } & Sangat Tidak Baik & 0 & 0 \\
\cline { 2 - 4 } & Jumlah & 122 & 100 \\
\hline
\end{tabular}


Dari Tabel 2 jawaban tentang keakuratan E-Journal ialah sebanyak $6(4,91 \%)$ responden menjawab sangat baik, $98(80,32 \%)$ responden menjawab baik, dan $18(14,75 \%)$ responden menjawab tidak baik. Maka dapat dilihat bahwa mahasiswa sangat terbantu dengan keakuratan E-Journal yang dilanggan oleh perpustakaan. Hal ini perlu ditingkatkan lagi dalam kata kunci dalam pencarian agar mempermudah mahasiwa dalam mencari artikel.

\subsubsection{Pertanyaan 2}

Pertanyaan 2 tentang Fasilitas Komputer yang disediakan sebagai media akses adalah sebagai berikut :

Tabel 3. Fasilitas Komputer

\begin{tabular}{|l|l|l|l|}
\hline Pertanyaan 2 & Pilihan Jawaban & Frekuensi & Presentase \\
\hline \multirow{3}{*}{$\begin{array}{l}\text { Bagaimana penilaian Anda } \\
\text { tentang fasilitas komputer } \\
\text { yang disediakan dalam hak } \\
\text { akses E Journal }\end{array}$} & Sangat Baik & 18 & 14,75 \\
\cline { 2 - 4 } & Baik & 92 & 75,40 \\
\cline { 2 - 4 } & Tidak Baik & 12 & 9,83 \\
\cline { 2 - 4 } & Sangat Tidak Baik & 0 & 0 \\
\cline { 2 - 4 } & Jumlah & 122 & 100 \\
\hline
\end{tabular}

Dari tabel 3 jawaban yang dapat di peroleh ialah sebanyak $18(14,75 \%)$ responden menjawab sangat baik, $92(75,40 \%)$ responden menjawab baik, dan $12(9,53 \%)$ responden menjawab tidak baik. Maka dapat dilihat bahwa mahasiswa menilai fasilitas komputer dalam hak akses E-Journal cukup baik. Hal ini perlu ditingkatkan lagi seperti perawatan hardware dan software yang menunjang pemanfaatan E-Journal.

\subsubsection{Pertanyaan 3}

Pertanyaan 3 tentang layanan E-Journal di Perpustakaan adalah sebagai berikut :

Tabel 3. Layanan E-Journal

\begin{tabular}{|l|l|l|l|}
\hline Pertanyaan 3 & Pilihan Jawaban & Frekuensi & Presentase \\
\hline \multirow{4}{*}{$\begin{array}{l}\text { Bagaimana layanan E- } \\
\text { Journal di Perpustakaan }\end{array}$} & Sangat Baik & 6 & 4,91 \\
\cline { 2 - 4 } & Baik & 92 & 75,40 \\
\cline { 2 - 4 } & Tidak Baik & 24 & 19,67 \\
\cline { 2 - 4 } & Sangat Tidak Baik & 0 & 0 \\
\cline { 2 - 4 } & Jumlah & 122 & 100 \\
\hline
\end{tabular}

Dari tabel 3 jawaban yang dapat di peroleh ialah sebanyak $6(4,91 \%)$ responden menjawab sangat baik, 92 $(75,40 \%)$ responden menjawab baik, dan $24(19,67 \%)$ responden menjawab tidak baik. Maka dapat dilihat bahwa mahasiswa menilai layanan E-Journal yang dilanggan cukup baik. Hal ini perlu ditingkatkan lagi agar mahasiswa sangat terbantu atas adanya fasilitas E-Journal.

\subsubsection{Pertanyaan 4}

Pertanyaan 4 tentang layanan E-Journal di Perpustakaan adalah sebagai berikut :

Tabel 4. Hak akses dari rumah

\begin{tabular}{|l|l|l|l|}
\hline Pertanyaan 4 & Pilihan Jawaban & Frekuensi & Presentase \\
\hline \multirow{3}{*}{} & Selalu & 14 & 11,47 \\
\cline { 2 - 4 } & Sering & 34 & 27,86 \\
\hline
\end{tabular}




\begin{tabular}{|l|l|l|l|}
\multirow{4}{*}{$\begin{array}{l}\text { Apakah anda membutuhkan } \\
\text { hak akses dari rumah dalam } \\
\text { pemanfaatan E-Journal }\end{array}$} & Kadang-kadang & 70 & 57,37 \\
\cline { 2 - 4 } & Tidak Pernah & 4 & 3,27 \\
\cline { 2 - 4 } & Jumlah & 122 & 100 \\
\hline
\end{tabular}

Dari tabel 4 jawaban yang dapat di peroleh ialah sebanyak $14(11,47 \%)$ responden menjawab selalu, 34 $(27,86 \%)$ responden menjawab sering, $70(57,37 \%)$ responden menjawab kadang-kadang dan $4(3,27 \%)$ responden menjawab tidak pernah. Maka dapat dilihat bahwa mahasiswa sangat membutuhkan hak akses E-Journal dari rumah. Hal ini perlu ditingkatkan lagi agar mahasiswa sangat terbantu atas adanya fasilitas E-Journal.

\subsubsection{Pertanyaan 5}

Pertanyaan 5 tentang kenyamanan ruangan adalah sebagai berikut :

Tabel. 5 Kenyamanan ruangan

\begin{tabular}{|l|l|l|l|}
\hline Pertanyaan 5 & Pilihan Jawaban & Frekuensi & Presentase \\
\hline \multirow{4}{*}{$\begin{array}{l}\text { Seberapa nyaman ruangan } \\
\text { hak akses E-Journal }\end{array}$} & Sangat Baik & 18 & 14,75 \\
\cline { 2 - 4 } & Baik & 94 & 77,04 \\
\cline { 2 - 4 } & Tidak Baik & 8 & 6,55 \\
\cline { 2 - 4 } & Sangat Tidak Baik & 2 & 1,63 \\
\cline { 2 - 4 } & Jumlah & 122 & 100 \\
\hline
\end{tabular}

Dari tabel 5 jawaban yang dapat di peroleh ialah sebanyak $18(14,75 \%)$ responden menjawab sangat baik, $94(77,04 \%)$ responden menjawab baik, 8 (6,55\%) responden menjawab tidak baik dan $2(1,63 \%)$ sangat tidak baik. Maka dapat dilihat bahwa mahasiswa menilai ruangan yang digunakaan hak akses E-Journal cukup baik. Hal ini perlu ditingkatkan lagi agar mahasiswa sangat terbantu atas adanya fasilitas E-Journal.

\subsubsection{Pertanyaan 6}

Pertanyaan 6 tentang penggunan E-Journal adalah sebagai berikut :

Tabel 6. Penggunaan E-Journal

\begin{tabular}{|l|l|l|l|}
\hline Pertanyaan 6 & Pilihan Jawaban & Frekuensi & Presentase \\
\hline \multirow{4}{*}{$\begin{array}{l}\text { Apakah Anda sering } \\
\text { mengalami kesulitan dalam } \\
\text { hal penggunaan E-Journal }\end{array}$} & Selalu & 6 & 4,91 \\
\cline { 2 - 4 } & Sering & 22 & 18,03 \\
\cline { 2 - 4 } & Kadang-kadang & 80 & 65,57 \\
\cline { 2 - 4 } & Tidak Pernah & 14 & 11,47 \\
\cline { 2 - 4 } & Jumlah & 122 & 100 \\
\hline
\end{tabular}

Dari tabel 6 jawaban yang dapat di peroleh ialah sebanyak $6(4,91 \%)$ responden menjawab selalu, 22 $(18,03 \%)$ responden menjawab sering, $80(65,57 \%)$ responden menjawab kadang-kadang dan $14(11,47 \%)$ responden menjawab tidak pernah. Maka dapat dilihat bahwa mahasiswa terlihat kesulitan dalam memakai fasilitas E-Journal yang dilanggan . Hal ini perlu ada perubahan pengenalan tentang cara pemanfaatan EJournal.

\subsubsection{Pertanyaan 7}

Pertanyaan 7 tentang pemandu fasilitas E-Journal adalah sebagai berikut : 
Tabel 7. Pemandu fasilitas E-Journal

\begin{tabular}{|l|l|l|l|}
\hline Pertanyaan 7 & Pilihan Jawaban & Frekuensi & Presentase \\
\hline \multirow{4}{*}{$\begin{array}{l}\text { Apakah anda sering dibantu } \\
\text { oleh pustakawan dalam } \\
\text { pencarian artikel di E-Journal }\end{array}$} & Selalu & 0 & 0 \\
\cline { 2 - 4 } & Sering & 8 & 6,55 \\
\cline { 2 - 4 } & Kadang-kadang & 60 & 49,18 \\
\cline { 2 - 4 } & Tidak Pernah & 54 & 44,26 \\
\cline { 2 - 4 } & Jumlah & 122 & 100 \\
\hline
\end{tabular}

Dari tabel 7 jawaban yang dapat di peroleh ialah sebanyak $8(6,55 \%)$ responden menjawab sering, 60 $(49,18 \%)$ responden menjawab kadang-kadang dan $54(44,26 \%)$ responden menjawab tidak pernah. Maka dapat dilihat bahwa mahasiswa terlihat butuh di bantu oleh pustkawan dan dilain pihak mahasiwa juga tidak perlu sungkan meminta bantuan. Hal ini perlu ada perubahan pengenalan tentang cara pemanfaatan EJournal.

\subsubsection{Pertanyaan 8}

Pertanyaan 8 tentang pemanfaatan fasilitas E-Journal adalah sebagai berikut :

Tabel 8. Pemanfaatan fasilitas E-Journal

\begin{tabular}{|l|l|l|l|}
\hline Pertanyaan 8 & Nilai & Frekuensi & Presentase \\
\hline \multirow{4}{*}{$\begin{array}{l}\text { Seberapa sering anda } \\
\text { menggunakan fasilitas E- } \\
\text { Journal }\end{array}$} & Selalu & 4 & 3,27 \\
\cline { 2 - 4 } & Sering & 30 & 24,59 \\
\cline { 2 - 4 } & Kadang-kadang & 88 & 72,13 \\
\cline { 2 - 4 } & Tidak Pernah & 0 & 0 \\
\cline { 2 - 4 } & Jumlah & 122 & 100 \\
\hline
\end{tabular}

Dari tabel8 jawaban yang dapat di peroleh ialah sebanyak $4(3,27 \%)$ responden menjawab selalu, sebanyak $30(24,59 \%)$ responden menjawab sering, $88(72,13 \%)$ responden menjawab kadang-kadang. Maka dapat dilihat bahwa mahasiswa membutuhkan fasilitas E-Journal yang dilanggan. Hal ini perlu dipertahankan agar minat mahasiswa membaca artikel dari E-Journal tetap tinggi.

\subsubsection{Pertanyaan 9}

Pertanyaan 9 tentang minat pemanfaatan fasilitas E-Journal adalah sebagai berikut :

Tabel 9 . Minat pemanfaatan fasilitas E-Journal

\begin{tabular}{|l|l|l|l|}
\hline Pertanyaan 9 & Pilihan Jawaban & Frekuensi & Presentase \\
\hline \multirow{4}{*}{\begin{tabular}{l} 
Seberapa antusias Anda \\
terhadap pemanfaatan E- \\
\multirow{3}{*}{ Journal }
\end{tabular}} & Sangat Positif & 30 & 24,59 \\
\cline { 2 - 4 } & Positif & 90 & 73,77 \\
\cline { 2 - 4 } & Negatif & 2 & 1,63 \\
\cline { 2 - 4 } & Sangat Negatif & 0 & 0 \\
\cline { 2 - 4 } & Jumlah & 122 & 100 \\
\hline
\end{tabular}

Dari tabel 9 jawaban yang dapat di peroleh ialah sebanyak 30 (24,59\%) responden menjawab sangat positif, sebanyak $90(73,77 \%)$ responden menjawab positif, $2(1,63 \%)$ responden menjawab negatif. Maka dapat 
dilihat bahwa mahasiswa sangat antusias terhadap fasilitas E-Journal yang dilanggan. Hal ini perlu dipertahankan agar minat mahasiswa membaca artikel dari E-Journal tetap tinggi.

\subsubsection{Pertanyaan 10}

Pertanyaan 10 tentang tampilan E-Journal adalah sebagai berikut :

Tabel 10. Tampilan E-Journal

\begin{tabular}{|l|l|l|l|}
\hline Pertanyaan 10 & Pilihan Jawaban & Frekuensi & Presentase \\
\hline \multirow{4}{*}{$\begin{array}{l}\text { Bagaimana interface dalam } \\
\text { E-Journal yang dilanggan }\end{array}$} & Sangat Baik & 12 & 9,83 \\
\cline { 2 - 4 } & Baik & 98 & 80,32 \\
\cline { 2 - 4 } & Tidak Baik & 12 & 9,83 \\
\cline { 2 - 4 } & Sangat Tidak Baik & 0 & 0 \\
\cline { 2 - 4 } & Jumlah & 122 & 100 \\
\hline
\end{tabular}

Dari tabel 10 jawaban yang dapat di peroleh ialah sebanyak $12(9,83 \%)$ responden menjawab sangat baik, $98(80,32 \%)$ responden menjawab baik, dan $12(9,83 \%)$ responden menjawab tidak baik. Maka dapat dilihat bahwa mahasiswa menilai tampilan yang digunakaan E-Journal cukup baik. Hal ini perlu ditingkatkan lagi agar mahasiswa tidak kesulitan pada tampilan fasilitas E-Journal.

\subsubsection{Pertanyaan 11}

Pertanyaan 11 tentang hubungan perkuliahan dengan E-Journal adalah sebagai berikut :

Tabel 11. Hubungan perkuliahan dengan E-Journal

\begin{tabular}{|l|l|l|l|}
\hline Pertanyaan 11 & Pilihan Jawaban & Frekuensi & Presentase \\
\hline \multirow{4}{*}{$\begin{array}{l}\text { Bagaimana Penilaian anda } \\
\text { terhadap E-Journal yang } \\
\text { dilanggan terhadap } \\
\text { perkuliahan }\end{array}$} & Sangat Positif & 8 & 6,55 \\
\cline { 2 - 4 } & Positif & 114 & 93,44 \\
\cline { 2 - 4 } & Negatif & 0 & 0 \\
\cline { 2 - 4 } & Sangat Negatif & 0 & 0 \\
\cline { 2 - 4 } & Jumlah & 122 & 100 \\
\hline
\end{tabular}

Dari tabel 11 jawaban yang dapat di peroleh ialah sebanyak $8(6,55 \%)$ responden menjawab sangat positif, dan sebanyak $114(93,44 \%)$ responden menjawab positif. Maka dapat dilihat bahwa mahasiswa menilai positif fasilitas E-Journal terhadap kuliahan yang dilanggan oleh universitas. Hal ini perlu dipertahankan agar bertambah minat mahasiswa terhadap artikel penlitian.

\subsubsection{Pertanyaan 12}

Pertanyaan 12 tentang Literasi Informasi di Perpustakaan adalah sebagai berikut :

Tabel 12. Literasi Informasi

\begin{tabular}{|l|l|l|l|}
\hline Pertanyaan 12 & Pilihan Jawaban & Frekuensi & Presentase \\
\hline \multirow{2}{*}{$\begin{array}{l}\text { Apakah Anda } \\
\text { menggunakan teknik } \\
\text { literasi informasi dalam } \\
\text { pencarian artikel di E- } \\
\text { Journal }\end{array}$} & Selalu & 8 & 3,27 \\
\cline { 2 - 4 } & Sering & 18 & 14,75 \\
\cline { 2 - 4 } & Kadang-kadang & 74 & 60,65 \\
\cline { 2 - 4 } & Tidak Pernah & 26 & 21,31 \\
\hline
\end{tabular}




\begin{tabular}{|l|l|l|l|} 
& Jumlah & 122 & 100 \\
\hline
\end{tabular}

Dari tabel 12 jawaban yang dapat di peroleh ialah sebanyak $4(3,27 \%)$ responden menjawab selalu, sebanyak $18(14,75 \%)$ responden menjawab sering,74 $(60,65 \%)$ responden menjawab kadang-kadang, dan $26(21,31 \%)$ responden menjawab tidak pernah Maka dapat dilihat bahwa mahasiswa membutuhkan ilmu literasi informasi. Hal ini perlu diterapkan agar mahasiswa dapat menemukan informasi dengan mudah tanpa membuang waktu yang lama.

\subsubsection{Pertanyaan 13}

Pertanyaan 13 tentang Proteksi di Perpustakaan adalah sebagai berikut :

Tabel 13. Proteksi

\begin{tabular}{|l|l|l|l|}
\hline Pertanyaan 13 & Pilihan Jawaban & Frekuensi & Presentase \\
\hline \multirow{4}{*}{$\begin{array}{l}\text { Seberapa terganggu dengan } \\
\text { proteksi E-Journal }\end{array}$} & Selalu & 8 & 6,55 \\
\cline { 2 - 4 } & Sering & 34 & 27,86 \\
\cline { 2 - 4 } & Kadang-kadang & 68 & 55,73 \\
\cline { 2 - 4 } & Tidak Pernah & 12 & 9,83 \\
\cline { 2 - 4 } & Jumlah & 122 & 100 \\
\hline
\end{tabular}

Dari tabel 13 jawaban yang dapat di peroleh ialah sebanyak $8(6,55 \%)$ responden menjawab selalu, sebanyak $34(27,86 \%)$ responden menjawab sering, 68 (55,73\%) responden menjawab kadang-kadang, dan $12(9,83 \%)$ responden menjawab tidak pernah . Maka dapat dilihat bahwa mahasiswa membutuhkan sangat terganggu dalam hal proteksi seperti menemukan judul yang dicari tetapi tidak ada full text yang dapat di unduh. Hal ini perlu di evaluasi oleh perpustakaan

\subsubsection{Pertanyaan 14}

Pertanyaan 14 tentang kecepatan Internet di Perpustakaan adalah sebagai berikut :

Tabel 14. Kecepatan Internet

\begin{tabular}{|l|l|l|l|}
\hline Pertanyaan 14 & Pilihan Jawaban & Frekuensi & Presentase \\
\hline \multirow{4}{*}{$\begin{array}{l}\text { Bagaimana kecepatan } \\
\text { internet dalam hak akses E- } \\
\text { Journal }\end{array}$} & Sangat Baik & 20 & 16,39 \\
\cline { 2 - 4 } & Baik & 78 & 63,93 \\
\cline { 2 - 4 } & Tidak Baik & 22 & 18,03 \\
\cline { 2 - 4 } & Sangat Tidak Baik & 2 & 1,63 \\
\cline { 2 - 4 } & Jumlah & 122 & 100 \\
\hline
\end{tabular}

Dari tabel 14 jawaban yang dapat di peroleh ialah sebanyak $20(16,39 \%)$ responden menjawab sangat baik, $78(63,93 \%)$ responden menjawab baik, $22(18,03 \%)$ responden menjawab tidak baik dan $2(1,63 \%)$ sangat tidak baik. Maka dapat dilihat bahwa mahasiswa menilai kecepatan internet yang digunakaan hak akses E-Journal cukup baik. Hal ini perlu ditingkatkan lagi agar mahasiswa sangat terbantu atas adanya fasilitas E-Journal.

\subsubsection{Pertanyaan 15}

Pertanyaan 15 tentang mengunduh di Perpustakaan sebagai berikut :

Tabel 15. Mengunduh

\begin{tabular}{|l|l|l|l|}
\hline Pertanyaan 15 & Pilihan Jawaban & Frekuensi & Presentase \\
\hline
\end{tabular}




\begin{tabular}{|l|l|l|l|}
\hline \multirow{4}{*}{$\begin{array}{l}\text { Bagaimana kecepatan } \\
\text { internet untuk mengunduh } \\
\text { artikel di E-Journal }\end{array}$} & Sangat Baik & 12 & 9,83 \\
\cline { 2 - 4 } & Baik & 86 & 70,49 \\
\cline { 2 - 4 } & Tidak Baik & 22 & 18,03 \\
\cline { 2 - 4 } & Sangat Tidak Baik & 2 & 1,63 \\
\cline { 2 - 4 } & Jumlah & 122 & 100 \\
\hline
\end{tabular}

Dari tabel 15 jawaban yang dapat di peroleh ialah sebanyak $12(9,83 \%)$ responden menjawab sangat baik,86 $(70,49 \%)$ responden menjawab baik, $22(18,03 \%)$ responden menjawab tidak baik dan $2(1,63 \%)$ sangat tidak baik. Maka dapat dilihat bahwa mahasiswa menilai kecepatan internet yang digunakaan untuk mengunduh artikel cukup baik. Hal ini perlu ditingkatkan lagi agar mahasiswa sangat terbantu atas adanya fasilitas E-Journal.

\subsubsection{Pertanyaan 16}

Pertanyaan 16 tentang virus komputer di Perpustakaan adalah sebagai berikut :

Tabel 16. Virus Komputer

\begin{tabular}{|l|l|l|l|}
\hline Pertanyaan 16 & Pilihan Jawaban & Frekuensi & Presentase \\
\hline \multirow{3}{*}{$\begin{array}{l}\text { Seberapa sering virus yang } \\
\text { ditularkan dari komputer } \\
\text { yang disediakan dalam hak } \\
\text { akses E-Journal }\end{array}$} & Selalu & 4 & 3,27 \\
\cline { 2 - 4 } & Sering & 32 & 26,22 \\
\cline { 2 - 4 } & Kadang-kadang & 54 & 44,26 \\
\cline { 2 - 4 } & Tidak Pernah & 32 & 26,22 \\
\cline { 2 - 5 } & Jumlah & 122 & 100 \\
\hline
\end{tabular}

Dari tabel 16 jawaban yang dapat di peroleh ialah sebanyak $4(3,27 \%)$ responden menjawab selalu, sebanyak $32(26,22 \%)$ responden menjawab sering , $54(44,26 \%)$ responden menjawab kadang-kadang, dan $32(26,22 \%)$ responden menjawab tidak pernah Maka dapat dilihat bahwa mahasiswa terdampak penularan virus komputer yang disediakan . Hal ini perlu adanya perawatan hardware maupun software komputer tersebut.

\subsubsection{Pertanyaan 17}

Pertanyaan 17 tentang gangguan listrik di Perpustakaan adalah sebagai berikut :

Tabel. 17 Gangguan listrik

\begin{tabular}{|l|l|l|l|}
\hline Pertanyaan 17 & Pilihan Jawaban & Frekuensi & Presentase \\
\hline \multirow{4}{*}{$\begin{array}{l}\text { Apakah anda mengalami } \\
\text { gangguan listrik saat } \\
\text { pencarian artikel di E- } \\
\text { Journal }\end{array}$} & Selalu & 0 & 0 \\
\cline { 2 - 4 } & Sering & 12 & 9,83 \\
\cline { 2 - 4 } & Kadang-kadang & 24 & 19,67 \\
\cline { 2 - 4 } & Tidak Pernah & 86 & 70,49 \\
\cline { 2 - 4 } & Jumlah & 122 & 100 \\
\hline
\end{tabular}

Dari tabel 17 jawaban yang dapat di peroleh ialah sebanyak $12(9,83 \%)$ responden menjawab sering, 24 $(19,67 \%)$ responden menjawab kadang-kadang, dan 86 (70,49\%) responden menjawab tidak pernah . Maka dapat dilihat bahwa mahasiswa tidak terdampak gangguan listrik saat padam pada saat pencarian E-Journal 
. Hal ini perlu adanya apresiasi untuk perpustakaan, karena dapat meningkatkan penilaian pelayanan di perpustakaan.

\subsubsection{Pertanyaan 18}

Pertanyaan 18 ditampilkan dalam bentuk terbuka, agar mahasiswa dapat menulis subjek yang sedang diteliti. Adapun jawaban dapat dikelompokkan adalah sebagai berikut :

Tabel. 18 Pencarian Subyek

\begin{tabular}{|c|c|c|c|}
\hline Pertanyaan 18 & $\begin{array}{c}\text { Pengelompokan } \\
\text { Jawaban }\end{array}$ & Frekuensi & Presentase \\
\hline \multirow{4}{*}{$\begin{array}{c}\text { Subjek apa yang } \\
\text { anda cari dalam } \\
\text { menemukan artikel }\end{array}$} & Pengendalian & 18 & 14,75 \\
\cline { 2 - 4 } & Pengaruh Merek & 28 & 22,92 \\
\cline { 2 - 4 } & $\begin{array}{c}\text { Pengaruh } \\
\text { kualitas }\end{array}$ & 42 & 34,45 \\
\cline { 2 - 4 } & $\begin{array}{c}\text { Pengaruh } \\
\text { Promosi dan Harga }\end{array}$ & 34 & 27,86 \\
\cline { 2 - 4 } & Jumlah & 122 & 100 \\
\hline
\end{tabular}

Dari tabel 18 jawaban yang dapat di peroleh ialah sebanyak $18(27,86 \%)$ responden menjawab pengaruh promosi dan harga, $28(22,92 \%)$ responden menjawab pengaruh merek, dan $42(34,45 \%)$ responden menjawab pengaruh kualitas. Maka dapat dilihat bahwa mahasiswa lebih menyukai subyek pengaruh kualitas dalam bidang manajemen. Hal ini perlu adanya tinjauan dari perpustakaan agar terpenuhi kebutuhan mahasiswa.

\section{Simpulan}

Berdasarkan hasil penelitian ini terdapat hubungan positif antara oemanfaatan jurnal dengan kesediaan jurnal di perguruan tinggi. Hat tersebut terlihat Sebanyak 114 responden $(93,44 \%)$ menjawab positif tentang fasilitas E-Journal yang dilanggan dan Sebanyak $22(18,03 \%)$ responden menjawab sering kesulitan dalam memanfaatkan E-Journal . Kesulitan ini terjadi karena tidak mengetahui bahwa E-Journal yang disediakan oleh perpustakaan dapat diakses dari rumah. Kesulitan ini terjadi karena tidak mengetahui bahwa E-Journal yang disediakan oleh perpustakaan dapat diakses dari rumah. Sebanyak $30(24,59 \%)$ responden menjawab sangat positif, sebanyak $90(73,77 \%)$ responden menjawab positif, $2(1,63 \%)$ responden menjawab negatif. Maka dapat dilihat bahwa mahasiswa sangat antusias terhadap fasilitas EJournal yang dilanggan.

Berdasarkan hasil penelitian ini, saran yang disampaikan penulis adalah sebagai berikut:

a. Mahasiswa harus berperan aktif dalam mencari artikel dan mahasiswa harus mencatat Id dan Password yang disediakan oleh Perpustakaan untuk mengakses E-Journal dari rumah

b. Perpustakaan lebih mensosialisasikan tentang fasilitas E-Journal yang disediakan bahwa $7(11,47 \%)$ responden menjawab selalu, $17(27,86 \%)$ responden menjawab sering membutuhkan fasilitas E-Journal dari rumah, karena mahasiswa tidak mengetahui bahwa E-Journal dapat diakses dari rumah.

\section{Daftar Pustaka}

Berawi,I 2012, Mengenal Lebih Dekat Perpustakaan Perguruan Tinggi. Iqra, Vol. 01. http://repository.uinsu.ac.id/690/1/iqra\%27\%202012\%20vol.06\%20no.\%2001\%20\%20Copy\%20\%287\%29.pdf. Diakses tanggal 9 Februari 2017

Chauhan, Kaushal 2012. Selected Free E-Journals in Library and Information Sciencein Directory of Open Access Journals. Journal of Library \& Information 
Technology,Vol.32.http://publications.drdo.gov.in/ojs/index.php/djlit/article/view/2529/1309 diakses tanggal 18 Februari 2017

Hasan,Thamrin 2013, Kajian Pemanfaatan Jurnal Online Pada Perpustakaan Universitas Pekanbaru Riau.Gema Pustakawan, Vol.1. http://download.portalgaruda.org/article.php?article=106164\&val=2293. Diakses tanggal 17 Februari 2017

Indonesia. Undang-Undang Republik Indonesia 2007, Undang-Undang No 43 Tahun 2007 tentang Perpustakaan. Perpustakaan Nasional Republik Indonesia, Jakarta. http://htl.unhas.ac.id/form_peraturan/photo/094607UU\%20No.43\%20tahun\%202007\%20tentang\% 20Perpustakaan.pdf. Diakses tanggal 10 Februari 2017

M.Yusup,Pawit 2012, Perspektif Manajemen Pengetahuan Informasi,Komunikasi, Pendidikan dan Perpustakaan. Raja Grafindo Persada,Jakarta.

Mustafi \& HM,M.Najib 2013. Pemanfaatan E-Journal dalam memenuhi kebutuhan informasi ilmiah dikalangan civitas akademik Universitas Hasanudin. Jurnal Komunikasi,Vol.02.http://journal.unhas.ac.id/index.php/kareba/article/view/353/212 diakses tanggal 27 Mei 2017

N.Sari 2013. Metode Penelitian. http://eprints.undip.ac.id/40737/3/004_BAB_III.pdf. Diakses tanggal 26 Mei 2017

Ratnaningsih,2008, Menuju Perpustakaan Perguruan tinggi berkelas dunia,S.N,Jakarta.

Riduwan 2004. Metode dan teknik menyusun thesis, Alfabeta, Bandung.

Russydi, I 2014. Pemanfaatan E-Journal Sebagai Media Informasi Digital. Iqra, Vol. 08. http://oaji.net/articles/2015/1937-1430103772.pdf. Diakses tanggal 15 Februari 2017

Sawitri,Niken Dwi 2011, Pemanfaatan Koleksi E-Journal Bidang Ekonomi dan Bisnis Oleh Civitas Akademika Pada Perpustakaan Fakultas Ekonomi dan Bisnis (FEB) UIN Syarif Hidayatullah Jakarta,Skripsi Sarjana, UIN Syarif HidayatullahJakarta.http://repository.uinjkt.ac.id/dspace/bitstream/123456789/427/1/102614NIKEN\%20DWI\%20SAWITRY-FAH.PDF Diakses tanggal 20 Februari 2017

Sugiyono 2012, Metode Penelitian Kuantitatif,Kualitatif, dan R\&D , Alfabeta, Bandung.

Sugiyono 2015, Metode Penelitian Kuantitatif,Kualitatif, dan Kombinasi (Mixed Methods), Alfabeta, Bandung.

Sutarno NS 2004, Manajemen Perpustakaan, Sagung Seto,Jakarta.

Vasishta, S. \& Navijyoti 2011. Trends in the Use of E- Journals : A Case Study of PEC University of Technology ,Chandigardh. Library Philosophy and Practice.http://digitalcommons.unl.edu/cgi/viewcontent.cgi?article=1730\&context=libphilprac diakses tanggal 21 maret 2017 